\title{
Nick Cowling
}

\section{THE LITTLE THINGS}

THE BACK OF the van burst open. The once dark and enclosed space was flooded with a light brighter than Creation. Inside the van was Greg. Shackled and blindfolded and thirsty as Hell he had been in this state of captivity for longer than he cared to remember. His blindfold was torn off. In the painful brilliance of the Australian sun, Greg could just make out the shape of his captor.

'Get out ... and for God's sake don't do anything stupid,' growled the figure. Hesitantly, Greg stumbled out of the van. The pins and needles in his weak legs as well as his shackled hands slowed down his exit. Impatiently the figure, which Greg now realised was Memphis, shot his hand into the space and began half dragging his captive out before throwing him against the van.

Despite being blinded by the white sun Greg could tell Memphis was only inches from his face, with one of his hands firmly pressed into Greg's shoulder. 'Now, when your daddy paid me to escort your disappearing arse across the Nullarbor, he told me to at least make sure you were fed once. Now Greg this is very important so I want you to pay attention, okay buddy? Can you see me?'

Furiously blinking his eyes the heavily tattooed and bald Memphis came into sharp contrast. So did a dusty and cobbled-together diner on the side of a vast wasteland. There was nothing out here but red soil and blue sky.

'Yes,' Greg rasped. Hours without liquids were taking their toll. 'Good. You can also see where we are right? No sign of civilisation as far as the eye can see. If you try anything foolish I WILL GET YOU ... and to make sure of that ...' Greg's laboured breathing intensified as Memphis drew a large hand gun from its holster on his belt, flashing it about in the burning sun '... I will use Charlene here to make sure you never walk again. Unfortunately for you driving for hours on end is playing hell with my eyesight so instead of hitting your leg I could, accidently of course ...' 
Memphis raised the weapon to Greg's head until it was between his eyes, holding it there to hammer the point home. 'Now do we understand each other, buddy?' Greg furiously nodded his head, beads of sweat stinging his eyes. 'Super.' Memphis quickly withdrew the weapon and dropped his menacing tone. 'Now let's see if this place is still making pancakes at this hour, c'mon!' He cracked a huge smile, showing several missing teeth and one gold one.

They'd better have pancakes, Greg thought as Memphis unlocked the shackles. Upon entering the diner, neither man was surprised with the desolate surrounds within the place. A thin film of red dirt covered most of the surfaces and little or no attempt was made to keep the place clean. This was a place that humanity had forgotten. A waitress appeared with a quizzical look on her face, like she wasn't expecting any business. Her voice betrayed her surprise at the appearance of this odd couple. 'Hey. Anywhere you like.'

Greg cast a furtive glance at Memphis, who stared impassively back. 'We will take the booth darlin', he said, 'and two glasses of water if you could be so kind?' The waitress shrugged, rolled her eyes and tossed two badly-laminated menus on the counter before yelling something unintelligible at the chef out the back. Memphis plopped into his cushioned seat and began squirming, trying to get comfortable. Seeing Greg again staring at him he replied, 'Back problems, hazard of the job.'

Greg gingerly sat down. When both men were acquainted with their chairs the waitress emerged with two glasses. 'We will take the pancakes sweetie,' said Memphis, handing the waitress back the menus. Glancing at the two men she opened her mouth to comment, upon meeting Memphis' gaze she thought better of it and hurried to the kitchen. Memphis kept an eye on her until she had disappeared. He then turned back to Greg who was steadily gulping down the liquid; despite its yellow hue.

'Bet you've been looking forward to that.' Memphis chuckled, indicating the now empty glass. Spluttering and surfacing for air Greg nodded. 'Yeah. The stress of being kidnapped and assaulted has been taking its toll,' he sneered. Memphis wagged his finger. 'Now no need to get bitchy, we are men after all. Two men discussing business ...'

'And what business is that? What business could one of my Dad's 'associates' possibly have to discuss with me-in the middle of the desert in some piece-of-shit diner?'

Memphis scowled at Greg and then smiled. 'Now Greg, you know about the work I do for your dad, the things he pays me to do. When he gave me this 
job he was hazy on the detail of whether he wanted you returned safely or in a pine box. Now as you can see there is a shortage of pine out here, but there is a lot of dirt. Don't interrupt me again or you and the dirt will become a lot more familiar. Have you seen Casino?'

'Everyone's seen Casino.' Greg sneered.

Memphis nodded with satisfaction. 'Well ... there are a lot of holes in the desert.'

The Australian landscape threatened to envelop the diner at a moment's notice. The sun was beginning to lazily drift to the west. Where it should have cast long shadows it did not-nothing out here cast a shadow. It was just flat for eternity in every direction. Memphis looked out the window for the first time, surveying the landscape. 'There's a lot of history out there friend, and I'm guessing a lot of secrets too.'

Greg was observing Memphis with great interest. He had never been privy to his dad's 'dealings' and his relationship with his father left everything to be desired. He had only met Memphis once, with his full head of hair and mouth full of teeth-now he was viturally unrecognisable. The only thing that made Greg sure that this was the same man that he saw all those years ago were the eyes. Those intense, black eyes. Greg knew he was in deep, but just didn't think it was this deep.

'Look ... Memphis ...'

Memphis held up his hand and shook his head. 'Stop. You haven't earned the right to call me by that name. I don't know you nearly enough for you to call me that. I also don't care for you.'

Greg leaned back, crossed his arms and scoffed. 'You don't care for me?'

Memphis also leaned back in his chair, a slight smirk dancing across his face. 'Your dad payed me a lot of money to find you. Now I have to tell you I have already driven several thousand kilometres to be here and we aren't even in Victoria yet. I don't care for your problems or bitching, they are your concerns. All that interests me is delivering you, in one form or another, to your daddy's door.' He took a sip of his drink. 'Though I do have a question for you.' Memphis shifted forward, his hands clasped on the table-top. 'Why did you do it? I mean the idea crosses everyone's minds at one point or another, hell some people even do it! Just not to this degree, but what you did was one for the books!'

Greg groaned and ran his hands through his hair staring at Memphis. 'Yeah, sure, why not? The executioner might as well know why he's cutting off the head.'

Memphis sneered. 'Cute ... but if you'd be so kind?' 
Greg laughed. 'Yeah alright. Dad was always a prick you know? Don't pretend he isn't. I am his only child and he once hit me on Christmas Day, cos I woke him up. Wouldn't have mattered so much but I was seven and just a bit impressionable at that age. Some kids would try to get their parent's approval but after a while I just didn't give a toss. When he wasn't on some construction site he was at his mistresses' place. He didn't even notice when Mum killed herself.'

Greg cleared his throat and ploughed right in again. 'Heerrrmm . . . he never cared. He would tell me that when I hit eighteen I was out on my arse. At seventeen I started getting scared. I knew he kept money in his office I just didn't know how much. The arrogant bastard kept it in the drawers of his desk, unlocked. I spose it was his pay-off fund. He must have thought I didn't know or that I was too afraid of him. Whatever. I began packing my bags the day before my birthday, taking all the money with me and covering the drawers with papers to conceal what I took. The next day there was no party, just the front door left open for me. He wasn't all cold,' Greg finished sarcastically, 'he did buy me a bus ticket.'

Memphis looked amazed. 'Did you know just how much you had?'

Greg shook his head. 'No. After I left I just had a backpack on me with a few pairs of socks and undies. It took me about an hour to count it all and the numbers just kept on getting bigger. By the time I had finished I had $\$ 500,000$. I was set for life. I didn't have a passport but I knew I had to leave Melbourne. I jumped on a domestic headed for Perth. Far away from my dad and his shitty sphere-of-influence. When I arrived I jumped in a taxi and got pissed at the nearest local. I couldn't buy property, Dad would be watching the market for sure. So I stayed underneath the radar, squatting here and there. I was always looking over my shoulder. After a couple of months I relaxed and began to enjoy my new life ... and then you showed up and ruined everything.'

Memphis snorted. 'Someone had to wake you up. You were nothing but an idealistic little shit who took something that didn't belong to you ... a lot of something ... with no defined plan for the future. What the hell did you think would happen? You didn't even leave the country!'

Greg rolled up the sleeves on his shirt, revealing tattoos running down his right forearm. 'I just needed to leave, man. I just needed an exit. Plus he was prepared to have me rot on the streets, let's not forget that!' Greg now had tears welling in his eyes. Memphis could see it was coming; after the confession always come the breakdowns.

'Can you just tell him that you didn't fi ...' 
Memphis cut him off. 'No, I can't. I can't speak on your behalf, I can't hide you, and I can't tell him any other such BS. I gave your dad my word and I'm an honest man. I don't take any pleasure in what I do, but someone has to do it.' He added. 'However ... when the time comes, when I'm told to, I will keep it clean. I won't be sloppy and it will be over before you know it. That's the best I can do.' Memphis shrugged. To his credit he did look upset. 'Your dad pays me to fix things, and at the moment you're the only thing that needs fixing.'

The pancakes arrived. The breakfast staple was a thick, buttery yellow. It was amazing to Greg that such a decrepit and lonely place could serve such eye-catching food. Memphis tucked in. Noticing that Greg wasn't eating he added, 'C'mon you may as well enjoy what you have. The little things make all the difference. Trust me, the remainder of this trip will be the best days of your life.' He took a huge bite and added, 'It's only when we have nothing that we can enjoy everything.'

Greg looked despondently at this man. This preachy arsehole was now chastising him for not eating his pancakes! He was barely nineteen. How could he squeeze any joy from life now? He watched Memphis sawing through his meal. Those muscular, tattooed forearms were moving like hydraulics. Greg might be able to get the jump on the man if he ran fast enough and then ... then what? He would be shot. He had only one means out of here and he wasn't in control. Surrendering to the gravity of the situation Greg slowly stuck his fork into the pancakes. Shoving the doughy substance into his mouth he had to agree with Memphis. They were bloody good pancakes.

Fifteen minutes later they were on the road. The sun was a thin sliver of gold far on the horizon. Taking pity on his captive Memphis decided to let Greg ride shotgun. Driving down the endless road Greg noticed that Memphis was paying constant attention to the thin strip of asphalt in front of him. A silver flash caught Greg's gaze and he noticed the gun. Memphis' gun! He stared at it, slowly forming a plan in his head. It was a brazen plan but in Greg's mind it was his only option. Memphis looked over at him, looked down at the gun still in its holster, and smiled 'You gotta be kidding $\mathrm{m}$...'

Memphis didn't get to finish his sentence. In the few seconds that his attention was drawn away from the road a red flash hopped into the vehicle's path, colliding with the van at speed. The kangaroo's impact knocked the vehicle into a ditch where it rolled before coming to a rest on its side. The lights of the van flickered violently casting a strobing effect over the road.

The van was now a pretzel of metal, fragmented glass, and what remained of

Offset no. IO $\mid 33$ 
the kangaroo. A figure painfully emerged from the remains and rested against the van, doubling over and coughing. The flickering headlights were just light enough to see the figure's right forearm-his tattooed right forearm. The headlights gave a final stuttering flash, and then died. Darkness fell over the outback revealing a faint light in the distance. The figure shuffled toward the light and disappeared into the landscape.

34 Offset no. Io 